\title{
Mai gyerek és az iskola
}

\author{
Wágner Éva \\ Deák-Diák Általános Iskola, Budapest
}

\begin{abstract}
A cikkben egy gyakorló pedagógus osztja meg gondolatait az iskolás gyerekek tanulásával kapcsolatban. Sok kérdés vetődik fel, hiszen a digitális korra nemcsak a változások, hanem ezek gyorsasága is jellemző. A napi nevelési kérdésekben ma sajnos gyakran nem áll rendelkezésünkre sok generáció által felhalmozott tudás. A mai gyerekeknek olyan tanulási utakat és lehetőségeket kínál a digitális világ, amelyeket a velük foglalkozó pedagógusoknak kemény munkával kell megismerniük. A digitális média átformálja a kisgyermekek játékait, tanulási és szabadidő-eltöltési szokásait. Ezek a lehetőségek befolyásolhatják azokat a képességeket, amelyek a hagyományosan értelmezett tanulási folyamatokhoz szükségesek. A szerző vizsgálja, hogyan viszonyul az intézményrendszer a tanulási környezet változásaihoz.
\end{abstract}

Kulcsszavak: a figyelem problémái, kommunikációs nehézségek, digitális tanulási környezet, újfajta tanulási utak

\section{Milyen is a mai gyerek az iskolából nézve?}

Aki ma egy első osztályban tanító pedagógust megkérdez arról, hogy milyenek a mai gyerekek, valószínűleg a következő válaszokhoz hasonlókat hall majd:

- Nagyon nehezen tudnak figyelni, szinte mindenkinek el kell mondanom mindent, újra és újra!

- Egyre többen vannak azok, akik nehézkesen fejezik ki magukat, és sokan az egyszerübb utasításokat sem értik.

- Nehéz a lépcsőn közlekedni velük, a járásban hamarabb elfáradnak, soknak rossz a mozgáskoordiációja.

- Lehetetlenség velük a korábbiaknak megfelelően haladni.

- Amúgy pont olyan aranyosak, mint a korábbiak, de valahogy mégis mások.

Szóval milyen is ez a mai gyerek? Valóban csak az idősebb generáció mindig szokásos zsörtölődését hallhatjuk, vagy esetleg most másról van szó?

\section{A családi környezet és változásai}

A mai családok mindennapjait a média és a fogyasztói társadalom gyökeresen átalakította. A változás, bár jelei már régebben láthatóak, nem ívelt át több generációt. Egymásfél évtized alatt gyökeresen megváltozott ez embereket körülvevő technikai-tárgyi környezet. A családok mindennapi életének visszavonhatatlanul része lett a média. Az utóbbi egy-két évtizedben a digitális média tölti ki a családi együttlétek nagy részét. $A$ gyermekeket születéstől fogva a korábbi generációkhoz képest merőben más tapasztalatszerzési, tanulási lehetőségeket kínáló környezet veszi körül. A digitális média fogyasztása szinte észrevétlenül alakította át a családok napi rutinját. A mai gyerekek rengeteg olyan tudással rendelkeznek, amelyek a korábbi generációk számára újak. Ezzel egyidejüleg kevésbé gyakorlottak olyan, régen hétköznapinak számító tudásokban, mint pl. a nagy- és a finommozgások szövevényes rendszerének birtoklása. 
A kisgyermekek jelentős része már két-három éves korától egyedül és önállóan keresi ki azt a játékot, amely őt leginkább szórakoztatja. TV-t néz és számítógépes játékot játszik, miközben kevesebbet beszélget és mozog. Bár a családok nagy részében tisztában vannak a mesélés és a beszélgetés fontosságával, az erre fordított idő ma lényegesen kevesebb, mint korábban. A családok mindennapjainak nemcsak a tudatos médiafogyasztás képezi részét, de egyre nagyobb számban vannak olyan családok is, ahol a TV és a számítógép használata mellett egyéb médiák is folyamatosan üzemelnek. A Nemzeti Média- és Hírközlési Hatóság felkérésére végzett kutatás (2012) adatai alapján is látható, hogy a mai 8-11 éves korosztály hétköznapokon átlagosan alig valamivel kevesebb, mint 1,5 órát ül a TV elött. Ha ezzel együtt azt is figyelembe vesszük, hogy ugyanez a korosztály ezen felül még majdnem 1 és $1 / 4$ órát tölt a számítógép képernyője előtt csak a hétköznapokon, akkor szinte biztosra vehető, hogy a gyerekek testi és szellemi fejlődésének valóban lehetnek a korábbiaktól eltérő sajátosságai.

\section{Miben is állhatnak ezek a sajátosságok?}

Mára sok kisgyermeknek saját digitális médiajátéka, vagy legalábbis játékideje van. Az ezekkel való játék ideje alatt sem nem mozog aktívan, sem pedig nem beszélget. Így értelemszerüen csökken az egyéni fejlődéshez elengedhetetlenül fontos mozgás és beszédinger szintje. Számos tanulmányból tudjuk, hogy a kisgyermek agyának fejlődésére milyen fontos hatása van a mozgásnak, és az ezzel együttjáró tapintásnak. A térbeliség „megtanulásához” kézbe kell fogni a tárgyakat, az anyagi tulajdonságok megismeréséhez tapasztalatokat kell szerezni például a hideg, meleg, az érdes, sima stb. tulajdonságokról.

A digitális világba beleszülető kisgyerekek természetes játékai, információszerzési módjai kapcsolódnak valamilyen képernyőhöz (Holloway, Green és Livingstone, 2013). Néhány éves korától megszokja, hogy saját maga irányíthatja játéktevékenységét, egyre önállóbban dönt annak tartalmáról és idejéről is. Így igazán nem meglepő, hogy más képességeik fejlődnek, mint azoknak, akik ezt az időt másfajta tevékenységre fordítják. Már jóval a betűk ismerete előtt is képesek elindítani, alakítani játékaikat, terveznek, építenek benne. Eközben megszokják, hogy a különböző információk bármikor ismételhetőek, az információk megértését, megtartását támogató animációkhoz hang is tartozik. Ezek az elemek megállíthatók, ismételhetők, sőt tetszés és érdeklődés szerint akár alakíthatók is. Ha egy-egy játékban ügyesek, azonnal pozitív értékelést kapnak, „feljebb jutnak” egy szinttel, ha nem, ismételhetnek, akárhányszor próbálkozhatnak újra. Ugyanakkor egy-egy játékelem vagy film nem tart túl sokáig, néhány percnél tovább nem tart a koncentrálás időszaka. A Nemzeti Média- és Hírközlési Hatóság egy 2013-ban végzett felmérése azt mutatja, hogy a 0-6 éves korosztály már aktív médiafogyasztóként éli mindennapjait. Az iskoláskor előtt napi 1-3 órát töltenek a kisgyermekek valamelyik „képernyős” eszköz előtt. Így igazán már nem is az a kérdés, hogy van-e hatása ennek az információszerzési forrásnak, tanulási módnak a kisgyermek fejlődésére, hanem az, hogy milyen ez a hatás!

\section{Hogyan tanul a mai gyermek?}

Az informáltságnak és az információözönnek azonban ára van. A digitális médiával születésétől fogva együttélő, kultúraváltó generáció fejlődésére értelemszerüen hat a környezet. Ez a hatás nemcsak a kognitív területeken jelenik meg, hanem a teljes fejlődési folyamatot átszervezi. Gyarmathy Éva így fogalmaz a mai gyermekekkel kapcsolatban: „A gyerekek automatikusan követik a kultúraváltást. Felnövekedett egy 
generáció, amely számára az írás, olvasás és számolás nehezen elsajátítható készségek, és az elemző, a viszonyokat, összefüggéseket értő, a következményeket követni képes gondolkodásmód alig müködőképes." (Gyarmathy, 2012)

A kisgyermek fejlődésének első, természetes közege a család. A családi tevékenységeknek, időtöltési szokások drámai megváltozása értelemszerűen hatással van a kisgyermek életvitelének alakulására is, hiszen a kisgyermek elsődlegesen a környezetében adódó mintákat figyeli meg és követi. A felnőttek és így az ő mintáikat követő kisgyermekek is, sokkal kevesebbet mozognak, mint korábban. A kevés mozgás a felnőtteknél egészségkárosodást okozhat, a kisgyermekeknél viszont a fejlődési folyamatokat befolyásolhatja. Ha csak arra gondolunk, hogy milyen fontos szerepe van a mozgásnak az agy fejlődésére, akkor érthető, hogy pusztán a mozgásos játékok és napi mozgás mennyiségének megváltozása is komolyan befolyásolhatja a tanulási folyamatokat (Farmosi, 1999). Ezért is egyre jobban felértékelődhet a gyermekintézmények szerepe, többek között a mozgásfejlesztésben.

Digitális médiahasználóként a tanulás rövid 2-7 perces időegységekben zajlik. Fontos eleme az önirányítottság, az egyéni érdeklődés azonnali kielégítése. Másik fontos eleme az azonnali visszajelzés és a hibázás, tévesztés szabad kijavítása. Az információegységek jellemzően egyszerre tartalmaznak hangot, mozgást és képeket, a folyamatok a teljes képernyő egészén zajlanak. A szem nem egy helyre koncentrál, az információk nem balról jobbra, fentröl lefelé követik egymást, mint az olvasás során, hanem a képernyő bármely részén felbukkanhatnak. A megismerés, a látvány egészleges, a figyelem sok egyidejü inger között oszlik meg.

Ebben a környezetben a gyerekek sokkal kevesebbet beszélnek, hiszen az aktivitások során nem egy másik emberrel, hanem egy géppel kommunikálnak, s ehhez nincsen szükség a gondolatok szavakba öntésére és ennek kimondására. Az információszerzés egyre inkább tolódik a vizuális közlések felé, és egyre kisebb a hangsúly a verbális közléseken. Így nem csoda, ha egyre többen úgy érzik, hogy növekszik az óvodások és elsősorban az iskolások között a beszédhibás gyermekek száma. A kevesebb beszédpróbálkozás során kevesebb alkalom adódik a hangok pontosabb kiejtésének gyakorlására, vagy a hallásészlelés pontosítására. Ez természetes módon befolyásolhatja az iskolában a tanulási folyamatokat.

Számos különböző tanulmány (Balázs, 2014) foglalkozik azzal, hogy milyen hatással van a kultúrára a digitális világ nagymértékủ térhódítása. Új fogalmak képződnek, mint például a másodlagos írásbeliség, vagy felmerül az a kérdés is, hogy mi lesz a nyomtatott könyvekkel és a kézírással. Azzal érdemes számot vetnünk, hogy nem most éljük át az emberiség első nagy kultúraváltását, hiszen az írásbeliség térhódítása legalább ekkora változást hozott az emberi gondolkodás szerkezetében (Szécsy, 2007). A mai oktatási rendszer az írásbeliség kultúráján alakult ki, ez határozza meg tartalmait és módszer-együtteseit. Kialakulásához, fejlődéséhez évszázadok álltak rendelkezésre. Napjaink kultúraváltása ezzel szemben viharosan történik, nem sok időt hagy a hagyományos oktatási rendszereknek az eszmélésre.

A mai gyermekek a korai gyermekkortól kezdve olyan környezetben fejlődnek, amelyben nemcsak az önirányítás a jellemző, de a többféle információ-inger egyidejüsége. Az internet világában erre a "multitasking” ${ }^{1}$ kifejezést is szokták használni. A

\footnotetext{
A multitasking kifejezés jelentése: két vagy több tevékenység egyidejű végzése. Az egyén szempontjából ez azt jelenti, hogy a figyelem egyidejüleg két vagy több dolog között oszlik meg. Ez a különböző tevékenységek összecsúszását is eredményezheti, a jelenség elsősorban a fiatalokra jellemző. Folyhat hagyományos tevékenységekkel és különböző online tevékenységekkel is.
} 
mai gyerekek nemcsak otthon érzik magukat az ilyen élethelyzetekben, de igénylik is a többféle egyidejü ingert. Ha olyan környezetbe kerülnek, ahol a megszokott ingerektől el vannak zárva, sokan érzik magukat elveszettnek. A mai gyermek számára teljesen természetes hogy szól a zene, játszik egy játékkal, közben csetel, a háttérben müködik a TV és még a családi történésekre is figyel.

Változó világunkban a gyermekintézmények szerepe, feladata is formálódik, alakul. Különösen fontos, hogy hogyan reagálnak az intézmények a kisgyermekek családi szocializációjának és tanulási folyamatainak megváltozására.

\section{Gyermekintézmények feladatai és lehetőségei}

Az óvodás gyermek az óvodában hozzá alkalmazkodó hosszúságú foglalkozásokon vehet részt. Erről az Óvodai nevelés országos alapprogramja a következőként fogalmaz: „A gyermek egészséges, a tevékenységekben megnyilvánuló fejlődéséhez, fejlesztéséhez a napirend és a hetirend biztosítja a feltételeket, melyek a megfelelő időtartamú, párhuzamosan is végezhető, differenciált tevékenységek, valamint a gyermek együttműködő képességét, feladattudatát fejlesztő, növekvő időtartamú (5-35 perces) csoportos foglalkozások tervezésével, szervezésével valósulnak meg." Az óvodai munka szabályozása és így a tervezés is olyan foglalkozási időkereteket határoz meg, amelyek a kisgyermekek számára nem térnek el lényegesen a megszokottaktól.

Az általános iskolába kerüléskor drámaian megváltozik a gyermek körül a világ. Heti 25 kötelező tanórán kell részt venniük. Ezek hosszát a működést szabályozó 20/2012 EMMI rendelet 45 percben rögzíti: „Elméleti oktatás keretében a tanítási óra ideje negyvenöt perc. Az iskola ennél rövidebb vagy hosszabb tanítási órát is szervezhet azzal a megkötéssel, hogy a tanítási óra ideje kilencven percnél nem lehet hosszabb, és az egy tanítási napon a tanulók kötelező tanórai foglalkozásainak felső határára vonatkozó rendelkezések szerint tartható kötelező tanórai foglalkozások számításánál a tanítási órákat negyvenöt perces órákra átszámítva kell figyelembe venni." Míg az óvodai foglalkozásokon való részvételre a kisgyermek nem „kötelezhető”, addig az iskola tanórákon való részvétel alól nincsen felmentés. Amíg a nagycsoportos óvodások általában napi 2-3 félórás foglalkozáson vehetnek részt, addig a helyzet néhány héttel az óvoda „befejezése” után drámaian megváltozik: napi 5, 45 perces, kötelező tanórai foglalkozáson való részvétel lesz az elvárás.

Az iskolai tanóráknak nemcsak a hossza, hanem a szervezése és gyakran az alkalmazott módszerek is idegenül hatnak a kisgyermekekre. Amíg az óvodákban a csoportszobában a foglalkozások során a gyerekek egymás felé fordulva ülhetnek, addig az iskolában legtöbbször egymás mögötti padokban kapnak helyet. Az egymás felé fordított székekben lehetőség van a beszélgetésekre, amelyre a mai gyerekeknek nagy szükségük van. Az iskolában a hagyományos pedagógiai eljárások során a gyerekek beszélgetésének nincsen helye. Pedig digitális médiahasználók számára az intézményekben eltöltött idő ideális lehetőséget kínál a szociális kompetenciák és a beszéd begyakorlásához. Az óvodában rengeteg színes játék, tematikus játszóhely invitálja a gyerekeket a tevékenységekre. Az iskolai termek nagyobb része ehhez képest ingerszegény, az eszközök általában elzárva, szekrényekben kapnak helyet. A multitaskinglétre szocializálódott gyerekek számára az iskola gyakran ingerszegény környezetet jelent. Gyakorló pedagógusok tapasztalatai azt jelzik, hogy a gyerekek számára egyre nehezebb a tanári magyarázatra való koncentrálás.

A Nemzeti Alaptanterv elvileg lehetővé teszi az iskolába való fokozatos beszokásátállás két éves időszakra való elnyújtását: „Az alsó tagozat első két évében a tartalmi 
szabályozás lehetővé teszi, ösztönzi az ebben az életkorban a tanulók között tapasztalható különösen jelentős egyéni fejlődésbeli különbségek pedagógiai kezelését. $A z$ alsó tagozat harmadik-negyedik évfolyamán erőteljesebbé - a negyedik évfolyam végére már meghatározóvá - válnak az iskolai teljesítmény-elvárások által meghatározott tanítási-tanulási folyamatok." Ha azonban a kerettanterveket elemezni átgondoljuk, hogy milyen tartalmi követelményeknek kell a kisgyermekeknek megfelelniük, valamint azt is figyelembe vesszük, hogy mekkora mentális különbségek vannak a gyerekek között az iskoláskor kezdetén, beláthatjuk, hogy ez szinte megoldhatatlan feladat elé állítja a hagyományos módszerekkel dolgozó pedagógusokat.

Azt hiszem, bátran állíthatjuk, hogy a kisgyermek életében minden szempontból drámai változást hoz az iskola. A helyzet egyáltalán nem válik a gyermek számára könnyebbé azzal, hogy az iskolában könyveket és füzeteket is használhat, hiszen ezek alkalmazásához szükséges technikai tudással a legtöbben még nem rendelkeznek. Ahogyan arról korábban már szó esett, a gyerek a megjelenő információt totális képként kezeli, általában így tesz a könyvvel és a füzettel is. Egyre nehezebben találja meg a sor elejét, a lap tetejét, nehezen boldogul azzal, hogy ha elrontott valamit, azt hogyan javíthatja ki. Ez is egyik oka lehet annak, hogy az iskolai osztályokban egyre gyakrabban merül fel a különböző tanulási problémák lehetősége. A tanulási képességeket vizsgáló eljárásokat azonban szintén nem a digitális kor gyermekeire dolgozták ki, így nem lehetünk biztosak abban, hogy tényleges tanulási probléma, vagy csak a másfajta tanulási előzmény van egy-egy probléma hátterében (Gyarmathy és Kucsák, 2012). Sokan azt mondják, hogy nő a figyelemzavaros gyerekek száma. Elképzelhető, hogy igazuk van, de a korábbiak alapján talán az is elképzelhető, hogy a gyerekek másféle módon tudnak csak figyelni, mint ahogyan azt az iskola elvárja tőlük. Saját gyakorlatomban (Wagner, 2012) számtalan alkalommal szembesültem azzal, hogy a tanári magyarázatra nehezen figyelő gyerekek az 1:1 tanulási környezetben ${ }^{2}$ hatékonyan dolgoznak. Ha a tanulás során olyan eszközöket és lehetőségeket kínálunk a gyerekeknek, amelyeket ismerősnek éreznek, akkor a tanulás is eredményesebbé válhat.

\section{A tanító generáció felelőssége}

Az iskolai tanulási környezet kialakulásának történelmi gyökerei régi korokba nyúlnak vissza. A mai iskola az írásbeliséghez kötődő ismertközvetítésre alakult, beleértve a tartalmakat, a módszereket és az értékelési rendszert is. A történelmileg kialakult írásbeliség kedvez a lineáris, kis lépésekben építkező eljárásoknak, és egyáltalán nem tud mit kezdeni azzal, hogy a mai gyerekek másféle közegben szocializálódnak a tanulásra. A „multitaskinglét” az iskolában zavaró körülmény, hiszen a tanári magyarázat elvileg csak egyszer hangzik el, és nem hívható le akármikor, tetszés szerint. A tanítók megfeszített munkával elérik, hogy a kisgyermekek (a változatlan követelményeknek megfelelően) elboldoguljanak a füzetekkel, megfelelőn tartsák a ceruzát, megtanulják kezelni a könyveket.

A digitális bennszülöttek (Pransky, 2001) iskolai teljesítményének alakulása, tanulási folyamatainak sikeressége a digitális bevándorló pedagógusok kezében van. A változó képességrendszerekkel, merőben új, látens tanulásmódszertani tudással

\footnotetext{
2 1:1 tanulási környezeten olyan tanulási helyzetet értünk, amelyben - tanári irányítás mellett - minden gyerek önállóan dolgozik egy számítógépen.
} 
iskolába lépő generáció tanításához szükséges a gyermekek tanulási képességeinek ismerete és az ehhez való alkalmazkodás. A mindennapi pedagógiai munkában is elengedhetetlenül fontos a gyermekből való kiindulás, hiszen ha nem tudjuk, mire építhetünk a fejlesztés során, ha nem támaszkodunk a gyermekek erősségeire, akkor könnyen csorbát szenvedhet a tanulási folyamat. A kultúraváltó kor pedagógusainak különös felelössége van abban, hogy a ne szakadjon meg a kultúraközvetítés folyamatossága, a gyermekek számára fogyaszthatóvá váljon az irodalom, tanulható és érthető legyen a természettudomány.

\section{Irodalom}

Balázs Géza (2007): Az írásbeliség változásai. http://www.napkut.hu/naput_2007/2007_03/ 101.htm, utolsó letöltés: 2014.11.01.

Farmosi István (1999): Mozgásfejlődés. Dialóg Campus Kiadó, Budapest.

Gyarmathy Éva (2012): Ki van kulturális lemaradásban? Digitális Nemzedék Konferencia 2012. február 11. http://www.diszlexia.hu/Cikkek/DigiDege.pdf, utolsó letöltés: 2014.11.01.

Gyarmathy Éva és Kucsák Julianna (2012): A digitális bennszülöttek képességprofilja, Iskolakultúra, 43-53. http://epa.oszk.hu/00000/00011/00168/pdf/EPA00011_ Iskolakultura_2012-9_043-053.pdf utolsó letöltés:2014.11.01.

Holloway, D., Green,L. és Livingstone, S. (2013): Zero to eight. Young children and their internet use. LSE, London: EU Kids Online. http://eprints.Ise.ac.uk/52630/1/Zero_to_eight. pdf, utolsó letöltés:2014.11.01.

Kid.Comm 2 kutatási eredmények - a 8-14 éves gyerekek médiahasználati szokásai. Budapest, 2012. http://mediatorveny.hu/dokumentum/293/KidComm2_tanulmany.pdf, utolsó letöltés: 2014.11.01.

Prensky, M. (2001): Digital Natives, Digital Immigrants. On the Horizon, MCB University Press, 9. 5. sz.

Szécsy Gábor (2007): Kommunikáció és gondolkodás. Áron Kiadó, Budapest. http://mek. oszk.hu/10100/10123/10123.pdf, utolsó letöltés: 2014.11.01.

Wagner Éva (2014): Jó gyakorlat a tanulói laptopokkal támogatott 1:1 tanulási környezet iskolai alkalmazásában. http://videotorium.hu/hu/recordings/details/3329,Jo_gyakorlat_a_ tanuloi_laptopokkal_tamogatott_1_1_tanulasi_kornyezet_iskolai_alkalmazasaban, utolsó letöltés: 2014.11.01.

\section{Felhasznált dokumentumok}

20/2012. (VIII. 31.) EMMI rendelet http://jogszabalykereso.mhk.hu/cgi_bin/njt_doc. cgi?docid=154663.610156, utolsó letöltés: 2014.11.01.

363/2012. (XII. 17.) Korm. rendelet az Óvodai nevelés országos alapprogramjáról http://net. jogtar.hu/jr/gen/hjegy_doc.cgi?docid=A1200363.KOR, utolsó letöltés: 2014.11.01.

Szülői vélemények gyermekeik TV nézési szokásairól Nemzeti Média és Hírközlési Hatóság 2013 http://mediatanacs.hu/dokumentum/160957/gyermekek_tevenezesi_szokasai.pdf, utolsó letöltés: 2014.11.01.

Kerettanterv az általános iskolák 1-4 osztálya számára http://kerettanterv.ofi.hu/01_ melleklet_1-4/index_alt_isk_also.html, utolsó letöltés: 2014.11.01. 